\title{
Relationship between brand association and customer loyalty: The case of online retail industry
}

\author{
Le Thai Phong ${ }^{\text {a*, Tran Hanh Nga }}{ }^{\mathrm{a}}$, Nguyen Thi Hanh ${ }^{\mathrm{a}}$ and Nguyen Van Minh
}

\begin{tabular}{|c|c|}
\hline CHRONICLE & ABST RACT \\
\hline $\begin{array}{l}\text { Article history: } \\
\text { Received: November 4, } 2019 \\
\text { Received in revised format: No- } \\
\text { vember } 292019 \\
\text { Accepted: December 12, } 2019 \\
\text { Available online: } \\
\text { December 12, } 2019 \\
\text { Keywords: } \\
\text { Customer Loyalty } \\
\text { Brand Association } \\
\text { Brand Awareness } \\
\text { Brand Equity } \\
\text { Customers'Willing To Pay }\end{array}$ & $\begin{array}{l}\text { The purpose of this paper is to examine the relationship between two main dimensions, Brand As- } \\
\text { sociation and Customer Loyalty. Besides, the research is also conducted to test other relevant net- } \\
\text { works of Brand Awareness, Brand Equity and Customers' Willing To Pay. A survey of which } \\
\text { questionnaires using Likert Scale to online retailers' customers in the North, Central, and the South } \\
\text { ( } 8 \text { largest cities in Vietnam) was conducted to collect the data including } 380 \text { personally responded } \\
\text { answers. Scale Test, Exploratory Factor Analysis, Confirmatory Factor Analysis and Structural } \\
\text { Equation Modeling were used to prove concrete relationships amongst variances, understand fac- } \\
\text { tors, analyze the Goodness of Fit of the Measurement model and bring about regression weights, } \\
\text { respectively. The results authenticated that Brand Association and Brand Awareness produce re- } \\
\text { markable effects on Customer Loyalty. Brand Association holds a cardinal importance to Custom- } \\
\text { ers' Willing To Pay. Not only can the findings be of substance for academic purpose but also they } \\
\text { make a great contribution to the development of companies of which Customer's Loyalty is the } \\
\text { lynch pin. }\end{array}$ \\
\hline
\end{tabular}

\section{Introduction}

Currently, with a drastic increase in the number of start-up companies, all organizations find it progressively more challenging to establish a name for themselves in relevant industries. After scrutinization, it is believed to be brand that has major influence on a company's development. Brand which is regarded as the most invaluable asset for almost all organizations has been demonstrated as a contributing factor leading to Customer Loyalty, a customer's tool to examine a product's differentiation and uniqueness. Hence, companies are impelled to facilitate their decision-making process which mitigates some customerrelated problems (Aaker, 1991; Emari et al., 2012; Kremer \& Viot, 2012; Huang \& Sarigollu, 2011). It is believed that customers make a profound influence on a company's success. As a result, its satisfaction and loyalty are definitely causing organizations and researchers to be concerned for them becoming the lynch pin of any organizations and a proper defense against competitors. When an organization has a thorough understanding and fulfills their customers' needs and wants, the satisfaction is actually gained. After that, the intention to repurchase the product they used to use is believed to have a dramatic increase. Reversely, if a brand fails to keep customers' credit and a sense of satisfaction, there will hardly no rebuying in the future. Some factors are demonstrated to determine customers' satisfaction such as quality of products and services, price, situations and personal factors (Wilson et al., 2008). Brand Association, which is in a concrete relationship with Customer loyalty, differentiates its identification from competitors, which make a unique impression on customers' mind (Tilde et al., 2009). Keller (1993) strongly believed that Brand Association includes top spirits, brand knowledge, brand opinion and brand dominance. Brand knowledge is a full set of Brand Association related to brands. Researchers have studied Customer satisfaction in different directions, from measurement to its relationship to other business aspects. And the possibility is that the more association a brand can bring to customers' mind, the more purchasing intention customers have.

* Corresponding author. Tel.: +84975055299

E-mail address: lethaiphong@ftu.edu.vn (L. T. Phong)

(C) 2020 by the authors; licensee Growing Science, Canada doi: $10.5267 /$ j.msl.2019.12.012 
Up to now, it can be seen that there has been a multitude of studies about the positive relationship between Brand Association and Customer Loyalty, however, gaps still exist. Researchers may focus more on large-scale companies or traditional organizations without taking any brand that use online selling into consideration while it is this kind of online selling that considerably need more Brand Association in order that customers spend greater trust on their brand than competitors', which enhances customers' loyalty and willingness to pay more (Lassar et al., 1995). Moreover, little attention has been dedicated to other relevant factors such as Brand Awareness, Brand Equity and Brand Image that impact positively Customer Satisfaction and Customer Loyalty, especially amongst the young who have greater willingness to shopping online. With the aim to narrow the gaps aforementioned as well as understand the paramount importance of Brand Association on Customer Loyalty, the study is conducted based on a context of online retailers to assist other organizations in attaining substantive knowledge to develop their brands. Moreover, this research proves linkages amongst Brand Awareness, Customer's Willing To Pay and Customer Loyalty in order that companies have a general view of the issue. The idiosyncratic contribution of this study arises due to the inextricable relationships proved among relating-brand factors, which afford later academic researches as well as organizations' practical application.

The paper is constructed as follows, the upcoming section presents an overview of relevant literature review, then research methodology and data analysis, which are followed by structural model result along with detailed discussion. Conclusion section briefly explains several reasons involving in close relationship amongst those above factors. The final section concludes on the study findings as well as recommendations proposed for researches later on.

\section{Literature review}

\subsection{Brand and Brand Management}

Currently, an eminent brand is the lynchpin of many organizations (Broyles et al., 2009; Pappu \& Quester, 2006; Esch et al., 2006). A brand which is a unique feature namely, name, symbol, and design that differentiates an organization's products or services from competitors' makes a significant contribution to enhance the value of the offerings (Aaker, 1997; Solomon \& Stuart, 2002; Farquhar, 1989; Murphy, 1990; Neumeier, 2006; Schmitt, 1999). A substantive image, positive associations, and favorable attitudes formed through experienced memories are integral in creating a strong brand (Farquhar, 1989). Researchers believe that branding provides a plurality of substantive benefits to the industry. Firstly, a clear brand identity it helps marketers dramatically differentiate their organizations from their competitors (Keller, 2008; Aaker, 2007). Secondly, a successful branding assists firms reduce advertising costs thanks to increasing brand name's awareness (Keller \& Lehmann, 2006). Thirdly, branding supports a firm to become an outstanding leader among the competitors in the same product category (Keller, 2008). As a consequence, a desirable brand identity not only impels organizations to increase the profit margin resulting from Consumers' Willing To Pay a premium for products, but also it may lead to profitable brand extensions into the same or dissimilar market as well. Finally, certain aspects of branding help firms safeguard their product features through legal protection from counterfeiting (Keller, 2008; Keller \& Lehmann, 2006; Schmitt \& Simonson, 1997). The analysis of brand management is not available if the philosophy of science by Thomas Kuhn, a well-known contributor to "paradigms" knowledge, is not mentioned (Tilde et al., 2009). Throughout the 1985-2006 period, brand management based on two paradigms to prevailed: a positivistic point of departure and a constructivist or interpretive nature. The positivistic stance implies a viewpoint of a brand possessed by the marketer who assumes the responsibility for communication to a passive consumer and regards brand equity as "A manipulative lifeless artefact" (Hanby, 1999, p.12). The interpretive paradigm reflects the brand nature and brand equity's value as something rooted in the link between marketer and an active consumer "As holistic entities with many of the characteristics of living beings" (Hanby, 1999, p. 10) and "As a living entity" (Hanby, 1999, p. 12). It is seven approaches applied in discovering what the brand management actually is that results in seven different definitions. The seven approaches which are presented in a chronological order and divided into three main sections, the first period 19851992, the second period 1993-1999, the last one 2000-2006 have made great contribution to bring renewal relevant approaches out in a given time frame. In the 1985-1992 period (company/sender focus), the economic approach and the identity approach are initially derived from the research on the company, the sender of brand communication. While the economic approach concentrates on the capabilities to manage a brand via marketing mix elements as product, placement, price and promotion, and how these factors can be misused to impact on consumer brand choice, the identity approach concentrates on how the identity of the company can govern customers succinct brand message that is conveyed to all stockholders. In the 1993-1990 period (human/receiver focus), the consumer-based approach allows the brand to be connected with consumer associations. Keller (1993) invented an entirely new methodology to brand management which is perceived as a cognitive perception in customer's mind, in which it is believed that a strong brand holds strong, unique and favorable associations. The personality approach presents that consumers is predisposed to furnish brands with human-like personalities. It is the 'human' brand perspective and the consumer that are the core values in this approach where consumers endow brands with personalities which is used in a dialogue-based exchange of symbolic value for their individual identity expression and construction. The relational approach derives from the philosophical tradition of existentialism and phenomenal nature, implying that a paradigm shift is happening because they are very similar to the roots of the research method. In the 2000-2006 period (cultural/context focus), two approaches can be pinpoint in this period of time: the community approach and the cultural approach. The community approach in which the brand as the pivotal point of social interaction is derived from an anthropological research about so-called brand communities, where brand value is created and served as the pivotal point of social interaction among consumers, which furthers a thorough understanding of the consumption's social context to the overall view regarding 
about brand management. The cultural approach, in which the brand as part of the broader cultural fabric is the cultural approach which is akin to the community approach and influences millennium. The brand is a cultural anachronism in this approach, rejuvenating both anti-branding argument and a theory as to the creation of iconic brand.

\subsection{Brand Association}

Brand Association is related to information in the customer's mind about the brand, either positive or negative, linked to the node of the brain memory (Emari et al., 2012). Brand Association works as an information collecting tool to execute brand differentiation and brand extension (Osselaer \& Janiszewski, 2001). Initially, any information that unintentionally come in Brand Association is considerably connected to the brand name in consumer recall, and reflect the brand's image (Keller, 1993; Romaniuk \& Sharp, 2003). The higher the Brand Associations in the product, the more it will be remembered by the consumer and be loyal towards the brand. Brand Associations play an important role in differentiating one organization from the others, and create favorable attitudes towards organizational product, which is drastically beneficial to organization. Keller (1993) classifies Brand Associations into three categories, Brand attributes, Brand benefits and Brand attitudes. Brand attributes are those descriptive characteristics that features a product or service, what a customer thinks about a product or service's assets and what is related to its purchase intention (Keller, 1993). "Non-product-related attributes" and "product-related attributes" are the two types of brand attitudes which includes price information, packaging, user imagery or usage imagery. Brand benefits are the personal value consumers attach to the product or service attributes, that is, what consumers actually think the product or service could bring for them (Keller, 1993). Brand attitudes is defined as consumers' overall evaluations of a brand (Mitchell \& Olson, 1981). Brand attitudes are crucial because they often form the background for consumer behavior (Keller, 1993). It is true that Brand Association creates a copious amount of value for an organization. Firstly, it helps process information. Associations can serve to summarize a set of facts and specifications that customers would find it possible to handle and access. Secondly, Brand Association provides remarkable effects on product differentiation. For example, products as wine, perfume and clothing, Brand Association which includes attitudes, attribute, benefit and product quality can play an important role in separating this brand from the others. Thirdly, Brand Association provides reason-to-buy for customers. Many Brand Associations represent a basis for purchasing decisions and Brand Loyalty. When a product is improved in quality, packaging and attribute, customer may tend to use it and gradually it creates a loyalty in customers' mind. Lastly, basis for extensions is the result of having a successful Brand Association by creating a consistent feeling between the brand name and the new product or by providing a reason to buy the extension. Empirical results from Abdallah \& Abo-Rumman (2013) and Bhaya (2017) also proved a correlation between Brand Association and Customer Loyalty variables. We therefore test the following hypothesis:

$\mathbf{H}_{1}$ : Brand Association has a significant positive effect on Customer Loyalty.

\subsection{Impacts of Brand Awareness on Customer Loyalty.}

Brand Awareness is regarded as one of the brand assets that makes substantive contribution to enhance a brand value (Aaker, 1996; Keller, 2013). Lynch and Srull (1982) propose that information of an established brand is stored in the memory as associations' series. Moreover, consumers' awareness of a brand can bring in a sense of familiarity and commitment to the brand (Aaker, 1992). Researchers proved that Brand Awareness significantly impact on Brand Loyalty and equity (Pike \& Bianchi, 2016; Asif et al., 2015). Aaker (1991) demonstrated that Brand Awareness can positively affect loyalty and perceptions. There are previous researches measuring the linkage between Brand Awareness and Brand Loyalty (Jung \& Sung, 2008; Kim et al., 2009; Yoo \& Donthu, 2002; Yoo et al., 2000). Ghana (2015) successfully uses the regression equation to demonstrate the positive relationship between Brand Awareness and Customer Loyalty. Thus, we propose the following,

$\mathbf{H}_{2}$ : Brand Awareness has a significant positive effect on Customer Loyalty.

\subsection{Impacts of Brand Association on Customers' Willing To Pay}

Willingness to pay (WTP) is defined as "the amount a customer is willing to pay for his/her preferred brand over comparable/lesser brands of the same package size/quantity" (Netemeyer et al., 2004, p. 211), which suggests that the price is conceptualized with respect to a competitor or set of competitors that must be clearly specified (Aaker, 1996). According to Belch $\&$ Belch (2004), purchase intention pints to the consumer's purchase intention to a brand. The higher purchase intention is, the more likely it is to rebuy the products. Thus, purchase intention is the most important predictor of purchase behavior (Long-Yi, Jui-chi, 2012). Satvati et al. (2016) successfully prove that Brand Association have great impact on Customer's Willing To Pay by using Structural equation model (SEM). The result is that path coefficient is 0.51 and t-statistic is 7.09 , which means that there is a significant positive connection between Brand Association and Consumer's Willing To Pay. Bayraktar (2015) also shows the similar results. Therefore, the following hypothesis will be tested:

H3: Brand Association has a significant positive effect on Customer's Willing To Pay.

\section{Research Methodology}

\subsection{Questionnaires developed}

All items were measured using a five-point Likert-type scale, one of the best and most frequently used scales to measure opinions, due to its ease and balance (Zikmund, 2000), with level 1 - absolutely disagree, level 2 - disagree, level 3 - neutral, 
level 4 - agree, and level 5 - absolutely agree. The final questionnaires were sent and returned with a response of 380 customers by the questionnaires form below:

Table 1

Survey Questionnaires

\begin{tabular}{|c|c|c|}
\hline Item code & Statements & Compiled from \\
\hline I & Brand Association & \\
\hline ATB1 & It is appropriate to describe the products offered by online retailers as "up-market" & \multirow{12}{*}{$\begin{array}{l}\text { Keller (1993), } \\
\text { Al-Abdallah \& Abo- } \\
\text { Rumman (2003), } \\
\text { Bhaya, Z. (2017) }\end{array}$} \\
\hline ATB2 & It is appropriate to describe the products offered by online retailers as "tough" & \\
\hline ATB3 & It is appropriate to describe delivery service offered by online retailers as "fast" & \\
\hline ATB4 & It is appropriate to describe display offered by online retailers as "logic" & \\
\hline BEN1 & online retailers constantly have promotions for customers & \\
\hline BEN2 & I feel relaxing when using online retailers & \\
\hline BEN3 & Customers can save a copious amount of money when using online retailers & \\
\hline BEN4 & Private shops can earn money through online retailers by uploading information of products on it & \\
\hline ATT1 & online retailers 's staff always accommodate to customers' need & \\
\hline ATT2 & online retailers 's staff always listen to customers' feedback & \\
\hline ATT3 & online retailers 's staff always response to customers' questions in short time & \\
\hline ATT4 & online retailers 's staff always ask their customers for feedback to improve products and service & \\
\hline II & Willing To Pay & \\
\hline WTP1 & I am willing to pay higher price in online retailers & \multirow{4}{*}{$\begin{array}{l}\text { Bayraktar. A. (2015), } \\
\text { Mehdi et al. (2013) }\end{array}$} \\
\hline WTP2 & I am willing to pay when online retailers increase price & \\
\hline WTP3 & I use almost online retailers's product line such as: TV, clothes, smartphone... & \\
\hline WTP4 & I might borrow money to buy online retailers's products & \\
\hline III & Brand Awareness & \\
\hline BRAW1 & I associate shopping online with online retailers & \multirow{5}{*}{$\begin{array}{l}\text { Ghana (2015), } \\
\text { Oppong \& Phiri (2018) } \\
\text { \& Asif et al. (2015) }\end{array}$} \\
\hline BRAW2 & Advertising characters remind me of online retailers & \\
\hline BRAW3 & I always remember online retailers as one of the most frequently used brands & \\
\hline BRAW4 & I recall online retailers whenever you have shopping need & \\
\hline BRAW5 & I recall online retailers whenever I see "Sale Campaign in TV" & \\
\hline IV & Customer Loyalty & \\
\hline CL1 & Online retailers would be my first choice & \multirow{5}{*}{$\begin{array}{l}\text { Ghana }(2015) \\
\text { \& Al-Abdallah \& Abo- } \\
\text { Rumman (2003) }\end{array}$} \\
\hline CL2 & I introduce to friends and relatives & \\
\hline CL3 & I give feedback to develop online retailers' products and service & \\
\hline CL4 & I protect online retailers when someone else tarnish their image & \\
\hline CL5 & I still use online retailers' products and service even if it is in scandals & \\
\hline
\end{tabular}

\subsection{Research model}

Premised upon those three hypotheses aforementioned from Keller (1993), Oppong \& Phiri (2018), Chinomona \& Maziriri (2017) and Bayraktar (2015), the research model in this research is proposed as follows:

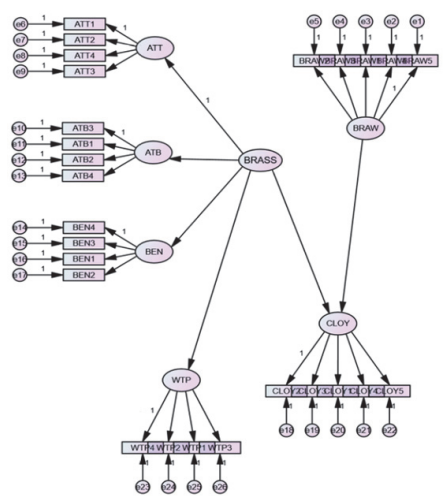

Fig. 1. Proposed research model (Source: Outputs from AMOS, 2019)

\subsection{Data Collection and Sampling description}

The data is assembled from online retailers' customers who have purchased online retailers, including Lazada, Shopee, Tiki, Sendo, Adayroi, at least once in the past 12 months in the North (Hanoi city, Haiphong city, Quangninh city), Central (Danang city, Hue city) and the South (Ho Chi Minh city, Binhduong city, Vungtau city). The distribution of sample is illustrated in Table 2. 
Table 2

Sample distribution

\begin{tabular}{lcccc}
\hline & North & Central & South & total \\
\hline Lazada & 37 & 23 & 48 & 32 \\
Shopee & 26 & 19 & 25 & 77 \\
Tiki & 21 & 11 & 39 & 57 \\
Sendo & 18 & 17 & 28 & 74 \\
Adayroi & 21 & 15 & 172 & 64 \\
total & 123 & 85 & & $\mathbf{3 8 0}$ \\
\hline
\end{tabular}

\section{Data Analysis}

\subsection{Data analysis procedures}

The study used a quantitative approach to determine whether or not Brand Associations (the independent variables) can affect consumer loyalty (the dependent variables). The research is carried out based on IBM SPSS and IBM AMOS, in which Cronbach's Alpha is to measure the scale's reliability, EFA to examine factors, CFA to confirm factors and structural equation modeling (SEM) to demonstrate the relation between Brand Association and Customer Loyalty.

\subsection{Reliability Analysis}

Nunnally (1978) and Peterson (1994) prove that a scale has internal consistency in case Corrected item-total correlation is equal or greater than 0.3 and Coefficient Alpha higher than 0.6. If Coefficient Alpha is greater than 0.8, then it has a good internal consistency.

Table 3

Cronbach's coefficient and Corrected Item-Total Correlation

\begin{tabular}{|c|c|c|}
\hline Observed variables & Corrected Item-Total Correlation & Cronbach's Alpha \\
\hline \multicolumn{3}{|l|}{ Attribute } \\
\hline ATB1 & 0.830 & \multirow{4}{*}{0.911} \\
\hline ATB2 & 0.791 & \\
\hline ATB3 & 0.841 & \\
\hline ATB4 & 0.740 & \\
\hline \multicolumn{3}{|l|}{ Benefit } \\
\hline BEN1 & 0.798 & \multirow{4}{*}{0.913} \\
\hline BEN2 & 0.807 & \\
\hline BEN3 & 0.791 & \\
\hline BEN4 & 0.818 & \\
\hline \multicolumn{3}{|l|}{ Attitude } \\
\hline ATT1 & 0.808 & \multirow{4}{*}{0.909} \\
\hline ATT2 & 0.818 & \\
\hline ATT3 & 0.706 & \\
\hline ATT4 & 0.846 & \\
\hline \multicolumn{3}{|l|}{ Brand Awareness } \\
\hline BRAW1 & 0.698 & \multirow{5}{*}{0.881} \\
\hline BRAW2 & 0.685 & \\
\hline BRAW3 & 0.684 & \\
\hline BRAW4 & 0.752 & \\
\hline BRAW5 & 0.754 & \\
\hline \multicolumn{3}{|l|}{ Customer Loyalty } \\
\hline CLOY1 & 0.653 & \multirow{5}{*}{0.870} \\
\hline CLOY2 & 0.794 & \\
\hline CLOY3 & 0.719 & \\
\hline CLOY4 & 0.694 & \\
\hline CLOY5 & 0.616 & \\
\hline \multicolumn{3}{|l|}{ Willing To Pay } \\
\hline WTP1 & 0.686 & \multirow{4}{*}{0.869} \\
\hline WTP2 & 0.750 & \\
\hline WTP3 & 0.666 & \\
\hline WTP4 & 0.788 & \\
\hline
\end{tabular}

\subsection{Explanatory Factor Analysis}

Hair at al. (2011) demonstrated that if $0.5<\mathrm{KMO}<1$, that sample is accepted to be taken to Factor Analysis and in this research, Kaiser-Meyer-Olkin Measure of Sampling Adequacy is 0.903, which is in the interval of (0.5; 1). Moreover, Hair at al. (2006) strongly indicated that if Bartlett's Test of Sphericity is equal or less than 0.05, that hypothesis is accepted. In this case, hypothesis H1: Brand Association have a significant positive effect on Customer Loyalty is valid because Significance of KMO is 0.000 . Confirmatory Factor Analysis is attained premised upon three key pillars, unidimensionality, construct validity, and indices of model fit. Unidimensionality is achieved when the factor loading extracted in each construct is positive and higher than 0.6. It can be seen from the measurement model that all latent constructs do extract positive factor loadings 
from items and they are all greater than 0.6, with the lowest belonging to the BRAW's extraction from BRAW3 at 0.71 . Construct validity constitutes convergent and discriminant validity. Convergent validity is met when Average Variance Extracted (AVE) is higher than 0.5, and Composite Reliability (CR) higher than 0.7 and higher than AVE simultaneously (Hair et al., 2006). The measurement model possessed the lowest AVE of 0.580 , higher than 0.5 and CR of 0.873 , thereby satisfying the aforementioned requisite. The indices of model fit are presented in Table 4, all of which passing the recommended cut-off points.

\section{Table 4}

Pattern Matrix

\begin{tabular}{|c|c|c|c|c|c|c|}
\hline Items classified into dimensions & Brand & Attitude & Attribute & Benefit & Customer Loyalty & Willing To Pay \\
\hline BRAW5 & 0.836 & & & & & \\
\hline BRAW4 & 0.831 & & & & & \\
\hline BRAW1 & 0.745 & & & & & \\
\hline BRAW3 & 0.729 & & & & & \\
\hline BRAW2 & 0.721 & & & & & \\
\hline ATT1 & & 0.905 & & & & \\
\hline ATT2 & & 0.895 & & & & \\
\hline ATT4 & & 0.872 & & & & \\
\hline ATT3 & & 0.690 & & & & \\
\hline ATB3 & & & 0.914 & & & \\
\hline ATB1 & & & 0.892 & & & \\
\hline ATB2 & & & 0.821 & & & \\
\hline ATB4 & & & 0.753 & & & \\
\hline BEN4 & & & & 0.884 & & \\
\hline BEN3 & & & & 0.842 & & \\
\hline BEN1 & & & & 0.841 & & \\
\hline BEN2 & & & & 0.834 & & \\
\hline CLOY2 & & & & & 0.944 & \\
\hline CLOY3 & & & & & 0.802 & \\
\hline CLOY1 & & & & & 0.717 & \\
\hline CLOY4 & & & & & 0.674 & \\
\hline CLOY5 & & & & & 0.587 & \\
\hline WTP4 & & & & & & 0.957 \\
\hline WTP2 & & & & & & 0.835 \\
\hline WTP1 & & & & & & 0.659 \\
\hline WTP3 & & & & & & 0.617 \\
\hline
\end{tabular}

\subsection{Confirmatory Factor Analysis}

Table 5 demonstrates the results of convergent and divergent validity of different constructs.

Table 5

Convergent and Divergent validity of constructs

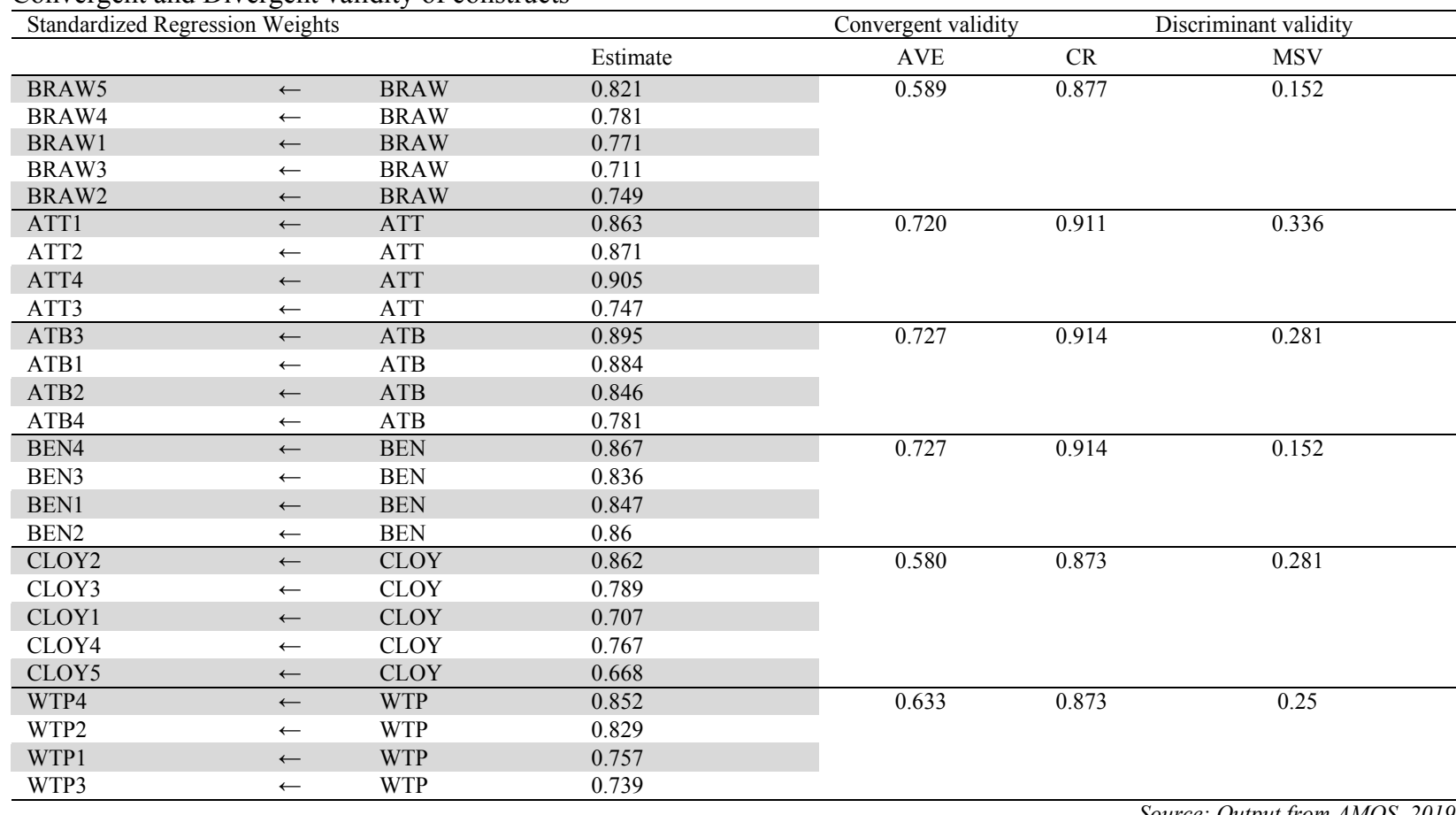




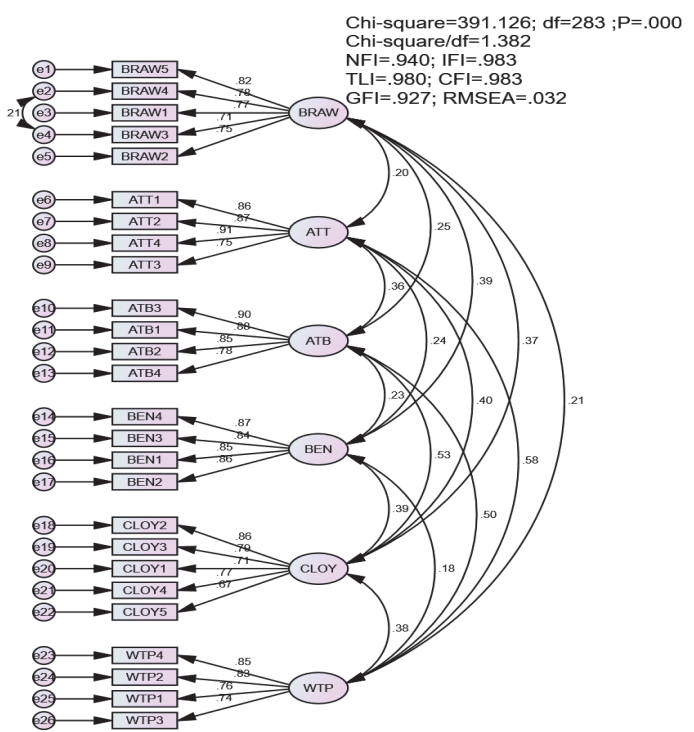

Fig. 2. Measurement Model with Standardized Estimates

Source: Output from AMOS, 2019

Table 6

Indices of model fit in the Measurement Model and Structural Model

\begin{tabular}{llll}
\hline Fit Index & Recommended cut-off point & Measurement model & Structural model \\
\hline Chi-square/df & less than 3 & 1.382 & 1.585 \\
Normed Fit Index (NFI) & greater than 0.9 & 0.940 & 0.930 \\
Comparative Fit Indexes (CFI) & greater than 0.9 & 0.983 & 0.973 \\
Incremental Fit Indices (IFI) & greater than 0.9 & 0.983 & 0.973 \\
Non-normed Fit Indexes/Tucker-Lewis Index (NNFI/TLI) & greater than 0.9 & 0.980 & 0.970 \\
Goodness of Fit Index (GFI) & greater than 0.9 & 0.927 & 0.915 \\
Root Mean-Square Error of Approximation (RMSEA) & less than 0.05 & 0.032 & 0.039 \\
\hline & & Source: Authors' summary from AMOS output, 2019
\end{tabular}

\section{Research results}

It is noticeable that all three hypotheses are accepted, H1, H2 and H3 because the critical ratios, C.R. of those three hypotheses are all greater than 1.96 and p-values of which are equal or less than 0.05 . It is worth mentioning that p-values of H1, H2 and $\mathrm{H} 3$ are less than 0.05 , which means that significance is $95 \%$ and the critical ratios of which are $7.597 ; 2.407 ; 8.538$, respectively, much greater than 1.96. Therefore, these factor covariances are accepted. Of those three hypotheses, H1, indicating the impact of Brand Association on Customer Loyalty, covers the most significant ratio with Estimate $\boldsymbol{\beta}=1.09 ; \mathrm{S} . \mathrm{E}=0.143$; critical ratio C.R. $=7.597$ and p-value less than 0.001 (significant at 99.9\%). Likewise, H2 indicating the impact of Brand Awareness on Customer Loyalty, also has a lower significant ratio than $\mathrm{H} 1$ but still a great covariance with Estimate $\boldsymbol{\beta}=$ 0.126 ; $\mathrm{S} . \mathrm{E}=0.052$; critical ratio C.R. $=2.407$ and $\mathrm{p}$-value $=0.016$ (significant at approximately $99 \%$ ). In short, it is true that both Brand Association and Brand Awareness considerably affect Customer Loyalty. Moreover, this research also proves a strong relationship between Brand Association and Customer's Willing To Pay that ratio Brand Association putting on Customer's Willing To Pay is significant positive with Estimate $\boldsymbol{\beta}=0.894$; S.E $=0.105$; critical ratio C.R. $=8.538$ and p-value less than 0.001 (significant at 99.9\%), which are all in accepted interval of research's requirements.

Table 7

Unstandardized regression weights

\begin{tabular}{|c|c|c|c|c|c|c|c|c|}
\hline & & & Estimate & S.E. & C.R. & $\mathbf{P}$ & Hypothesis & Conclusion \\
\hline WTP & $\leftarrow$ & BRASS & 0.894 & 0.105 & 8.538 & $* * *$ & H3 & Accepted \\
\hline CLOY & $\leftarrow$ & BRASS & 1.09 & 0.143 & 7.597 & $* * *$ & H1 & Accepted \\
\hline CLOY & $\leftarrow$ & BRAW & 0.126 & 0.052 & 2.407 & 0.016 & $\mathrm{H} 2$ & Accepted \\
\hline
\end{tabular}




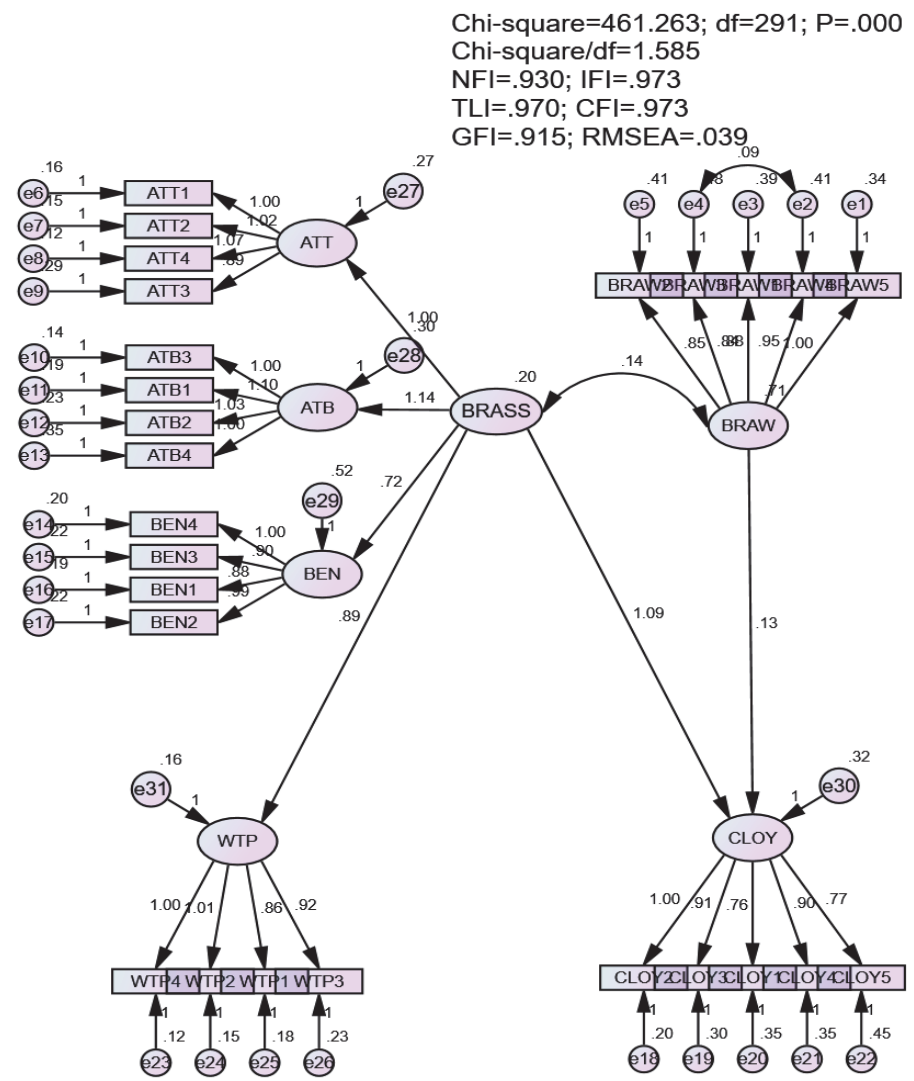

Fig. 3. Structural model with Unstandardized Estimates

\section{Discussion}

Brand Association and Customer Loyalty: It is proved that there is a concrete relationship between Brand Association and Customer Loyalty which is also the linkage between items of Brand Association and those of Customer Loyalty. When Brand Association including benefit, attribute, attitude and product quality meet customers' need, they tend to be more loyal to the brand. For example, when a product is more and more improved in quality and attractive packaging, customers will be likely to use that product for its outstanding attributes. The findings are in line with Al-Abdallah and Abo-Rumman (2013), LeClerc and Little (1997), and Bhaya (2017).

Brand Awareness and Customer Loyalty: The paper proved that Brand Awareness is of cardinal importance on Customer Loyalty. When a brand is more featured in customers' mind, they tend to use that brand's product because it creates a familiar feeling of customers on products. For example, when a person meets Tieu Vy, miss of Vietnam, he will remember Shopee because Tieu Vy endorses Shopee products. The findings are supported by previous studies, such as Jung and Sung (2008); Kim et al. (2009); Yoo and Donthu, (2002); Yoo et al. (2000); and Ghana (2015).

Brand Association and Customer's Willing To Pay: Interestingly, Brand Association does not have major influence on Customer's Willing To Pay. It might be that Brand Association includes attribute, attitude, benefit and product quality is appropriated, which may lead to such high price that customers do not have ability to pay. So, they will use product with lower quality but affordable price, especially in a context of emerging market like Vietnam. The advice is that besides improving items needed to foster Brand Association, a company should take price strategy into consideration so that customer can use good products but with reasonable price.

\section{Conclusion and Recommendations}

The research has been conducted to verify empirical relationships amongst four constructs of Brand Association, Brand Awareness, Customers' Willing To Pay and Customer Loyalty. The findings prove reliable as the indices of model fit pass the acceptable threshold, determined by previous studies. In addition, organizations can rely on the findings to make decisions regarding sale promotion. The initiative could be to direct limited resources into product quality, attribute, attitude and benefit. 
In order to have a thorough understanding about the research, the authors are, first, to have a big picture about the Brand as well as detailed concepts of each variables relevant. The authors also depended on previous researches to provide hypotheses and then employ methods such as EFA, CFA and SEM to measure those ones, which is accepted or rejected. This study has been implemented based on 380 responses from online retails' customers answering survey questionnaires in the North, Central and the South of Vietnam. There were several substantive findings proved in this research and all three hypotheses proved relevant, Customer Loyalty is ascribable to Brand Association, Brand Awareness is of cardinal importance on Customer Loyalty and Brand Association produces remarkable impacts on Customers' Willing To Pay. It is inevitable that there are several limitations in this research we should acknowledge. Firstly, the sample size of 380 observations may not be large enough to generalize enough to other research contexts. Future studies can have a larger-scale research with customers from different countries. Secondly, using convenient sampling is also a contributing factor leading to a compromise in the objectivity. Future researches, hence, should be circumspect in using probability sampling. Thirdly, this research has a small scale that only focus on online customers in 8 largest cities of Vietnam, which instigates limited results that do not cover all customers in all part of the world.

\section{Acknowledgement}

This paper is a product of Research Team “Applications of Advanced Management Tools into Vietnamese Settings”, Foreign Trade University, Vietnam.

\section{References}

Aaker, D. A. (1992). The value of brand equity. Journal of Business Strategy, 13(4), 27-32.

Aaker, D. A. (1996). Measuring brand equity across products and markets. California Management Review, $38(3), 102$ - 120.

Aaker, D. A. (2007). Strategic market management. Hoboken, NJ: John Wiley \& Sons.

Aaker, D.A. (1991). Managing Brand Equity: Capitalizing on the Value of a Brand Name. The Free Press New York, NY.

Aaker, J. L. (1997). Dimensions of brand personality. Journal of Marketing Research, 34(3), 347-356.

Al-Abdallah, G \& Abo-Rumman, H (2003). The effect of brand associations on customer loyalty: Empirical study on mobile devices in Jordan. American Academic \& Scholarly Research Journal, 5(1), 122 - 134.

Asif, M., Abbas, K., Kashif, M., Hussain, S. \& Hussain, I. (2015). Impact of brand awareness and loyalty on brand equity. Journal of Marketing \& Consumer Research, 12, 67-72.

Bayraktar, A. (2015). Are consumers really willing to pay more for favorable brand associations? The moderating role of product value and product risk level. Ege Academic Review, 15(4).

Belch. G.E. \& Belch. M.A. (2004). Advertising and Promotion an Integrated Marketing Communications Perspective. Boston: Mc Graw Hill.

Bhaya, Z. (2017). The impact of dimensions of brand association on customers satisfaction: An empirical study of the opinions of customers' samples on Zain Iraq's mobile cell phone company. American Scientific Research Journal for Engineering, Technology, and Sciences (ASRJETS), 30(1), 70-81.

Broyles, S. A., Schumann, D. W., \& Leingpibul, T. (2009). Examining brand equity antecedent/consequence relationships. Journal of Marketing Theory and Practice, 17(2), 145-161.

Chinomona, R \& Maziriri, E (2017). The influence of brand awareness, brand association and product quality on brand loyalty and repurchase intention: a case of male consumers for cosmetic brands in South Africa. Journal of Business and Retail Management Research, 12(1), 143-154.

Emari, H., Jafari, A. and Mogaddam, M. (2012). The mediatory impact of brand loyalty and brand image on brand equity. African Journal of Business Management, 6(17), 5692-5701.

Esch, F-R., Langer, T., Schmitt, B. H., \& Geus, P. (2006). Are brands forever? How brand knowledge and relationships affect current and future purchases. Journal of Product \& Brand Management, 15(20), 98-105.

Farquhar, P. H. (1989). Managing brand equity. Marketing Research, 1(3), 24-33.

Kremer, F., \& Viot, C. (2012). How store brands build retailer brand image. International Journal of Retail \& Distribution Management, 40(7), 528-543.

Ghana, I. (2015). The impact of brand awareness on customer loyalty: a case study of sinapi aba savings and loans ghana limited. South American Journal of Management, 1(1).

Hair, JR, J.F., Ringle, C.M. \& Sarstedt, M. (2011). PLS-SEM: Indeed a Silver Bullet. Journal of Marketing Theory and Practice, 19(2), 139-151.

Hanby, T. (1999). Brands dead or alive. Journal of Market Research Society, 41(1), 7-19.

Huang, R., \& Sarigöllü, E. (2011). How brand awareness relates to market outcome, brand equity, and the marketing mix. Journal of Business Research, 65, 92 - 99.

Jung, J., \& Sung, E. Y. (2008). Consumer-based brand equity: Comparisons among Americans and South Koreans in the USA and South Koreans in Korea. Journal of Fashion Marketing and Management, 12(1), 24-35.

Keller, K. L. (2008). Strategic brand management: Building, measuring, and managing brand equity. (3rd ed.). Upper Saddle River, NJ: Prentice Hall.

Keller, K. L. (2013). Strategic Brand Management: Building Measuring, and Managing Brand Equity. (4th ed.), England: Pearson Education Ltd. 
Keller, K.L. (1993), Conceptualizing, measuring, and managing customer-based brand equity, Journal of Marketing, 57(1), 1-22.

Keller, K.L. \& Lehmann, D.R. (2006). Brands and branding: Research findings and future priorities. Marketing Science, 25(6), 740 -759 .

Kim, E. Y., Knight, D. K., \& Pelton, L. E. (2009). Modeling brand equity of a U.S. apparel brand as perceived by Generation Y consumers in the emerging Korean market. Clothing and Textiles Research Journal, 27(4), 247-258.

Lassar, W., Mittal B., \& Sharma A. (1995) Measuring customer-based brand equity. Journal of Consumer Marketing, 12(4), 11-19.

LeClerc, F. \& Little, J.D.C. (1997). Can advertising copy make FSI coupons more effective? Journal of Marketing Research, 34(4), 473-84.

Long-Yi, L., \& Jui-Chi, L. (2012). The influence of store image and product perceived value on consumer purchase intention. Business and information.

Lynch Jr, J. G., \& Srull, T. K. (1982). Memory and attentional factors in consumer choice: Concepts and research methods. Journal of Consumer Research, 9(1), 18-37.

Mehdi, J.S., Mojganc, K., \& Masoud, J. (2013). Investigation of the effective factors on brand loyalty and repurchase intention (Case study: Iranian Consumers). Research Journal of Recent Sciences, 2(2), 10-17.

Mitchell, A. A., \& Olson, J. C. (1981). Are product attribute beliefs the only mediator of advertising effects on brand attitude. Journal of Marketing Research, 18, 318-32.

Murphy, J. (1990). Assessing the value of brands. Long Range Planning, 23, 23- 29.

Netemeyer, R.G., Krishan, B., Chris, P., Wang, G., Yagci, M., Dean, D., Ricks, J., \& Wirdh, F. (2004). Developing and validating measure of facets of customer-based brand equity. Journal of Business Research, 57(1), pp. 209-224.

Neumeier, M. (2006). The brand gap. Berkeley, CA: New Riders.

Nunnally, J. C. (1978). Psychometric theory (2 $2^{\text {nd }}$ ed.). New York: McGraw-Hill.

Oppong, P \& Phiri, A (2018). Impact of brand awareness and association on loyalty: The role of equity in plant medicine market in Kumasi, Ghana. African Journal of Business and Economic Research, 13(2), 163 - 181.

Osselaer, V., \& Janiszewski, C. (2001), Two ways of learning brand association, Journal of Consumer Research, $28(2), 202-223$.

Pappu, R., \& Quester, P. (2006). A consumer-based method for retailer equity measurement: Results of an empirical study. Journal of Retailing and Consumer Services, 13(5), 317-329.

Peterson, R.A. (1994). A meta-analysis of Cronbach's coefficient alpha. Journal of consumer research, 21, $381-391$.

Pike, S., \& Bianchi, C. (2016). Destination brand equity for Australia: testing a model of CBBE in short-haul and long-haul markets. Journal of Hospitality \& Tourism Research, 40(1), 114-134.

Romaniuk, J., \& Sharp, B. (2003). Measuring brand perceptions: testing quantity and quality. Journal of Targeting, Measurement and Analysis for Marketing, 11(3), 218-229.

Satvati, R. S., Rabie, M., \& Rasoli, K. (2016). Studying the relationship between brand equity and consumer behavior. International Review, (1-2), 153-163.

Schmitt, B. \& Simonson, A. (1997). Marketing Aesthetics: The Strategic Management of Brands, Identity, and Image. New York: The Free Press.

Schmitt, N. (1999). Method bias: The importance of theory and measurement. Journal of Organizational Behavior, 15, $393-398$.

Solomon, M. R., \& Stuart, E. W. (2002). Marketing: Real people, real choice. (2nd ed.). Upper Saddle River, NJ: Prentice Hall.

Tilde. H., Charlotte F.K. \& Mogens.B., (2009). Brand management, research, theory and practice.

Wilson, V.A. Zeithaml, M.J. Bitner, D.D. (2008). Gremler. Services Marketing. McGraw-Hill Education.

Yoo, B., \& Donthu, N. (2002). Testing cross-cultural invariance of the brand equity creation process. Journal of Product \& Brand Management, 11(6), 380-398.

Yoo, B., Donthu, N. and Lee, S. (2000). An examination of selected marketing mix elements and brand equity. Journal of the Academy of Marketing Science, 28(2), 195-211.

Zikmund, W.G. (2000). Business Research Methods. $6^{\text {th }}$ ed., The Dryden Press, Fort Worth.

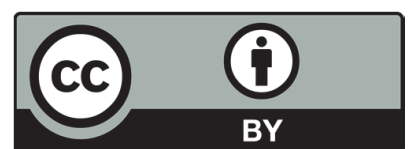

(C) 2020 by the authors; licensee Growing Science, Canada. This is an open access article distributed under the terms and conditions of the Creative Commons Attribution (CC-BY) license (http://creativecommons.org/licenses/by/4.0/). 